\title{
Experimental Analysis of the Status of Singapore's OFDI and Its Implications for China
}

\author{
Weijian Li, Chenggang $\mathrm{Li}^{*}$ \\ Business School, Beijing Institute of Fashion Technology, Beijing, China \\ Email: *ccid205@126.com
}

How to cite this paper: $\mathrm{Li}, \mathrm{W}$. J., \& Li, C. G. (2021). Experimental Analysis of the Status of Singapore's OFDI and Its Implications for China. Modern Economy, 12, 1795-1804. https://doi.org/10.4236/me.2021.1212092

Received: November 6, 2021

Accepted: December 13, 2021

Published: December 16, 2021

Copyright $\odot 2021$ by author(s) and Scientific Research Publishing Inc. This work is licensed under the Creative Commons Attribution International License (CC BY 4.0).

http://creativecommons.org/licenses/by/4.0/

\begin{abstract}
As a city-state, Singapore has created a series of economic glories in OFDI in recent years and has accumulated a wealth of investment experience. How to better carry out foreign investment, reduce losses and learn from Singapore's experience is of great practical significance for China to build an investment system. Based on the statistics of the World Investment Report of the United Nations Conference on Trade and Development, this paper analyzes the existing problems and makes suggestions through the quantitative analysis of Singapore's OFDI data, and summarizes the inspiration that Singapore has given to China in the field of OFDI.
\end{abstract}

\section{Keywords}

Singapore, OFDI, Investment Flows

\section{Introduction}

According to data released by the World Bank, Singapore's GDP was 340 billion yuan in 2020, with a per capita GDP of 598,000 yuan, ranking first in Asia. As a "newly industrialized country", Singapore's sustained and rapid economic development in recent decades has benefited not only from its good location advantages, high quality of its people and long-term stability of the political society but also from its long-standing adherence to its strategy of opening up to the outside world in line with its own national conditions. In Singapore's opening-up strategy, foreign trade, utilization of foreign capital and foreign investment have become important means to solve the shortage of resources, expand the development hinterland and obtain economic profits. There are two reasons for the rapid development of Singapore's OFDI: first, Singapore's small size, ${ }^{*}$ Corresponding author. 
Singapore's industrial structure is relatively single, the need to expand its industrial structure through OFDI, and second, because Singapore's local enterprises have developed so that these enterprises have excess capital and capacity. Today, OFDI has become Singapore's main channel of resource control and profit, and together with foreign trade and attracting foreign investment, it has become the three engines of Singapore's economic growth.

The article is organized as follows: firstly, it analyses the current situation of Singapore's OFDI in terms of its scale, distribution of industries and investment regions; secondly, it analyses the current problems of Singapore's OFDI and proposes corresponding solutions; finally, based on the above analysis, it summarizes the merits of Singapore's OFDI and its inspiration for China's OFDI.

\section{Research Status of Singapore's OFDI}

For Singapore's OFDI, many domestic scholars have put forward their own views. Hao (1997) believes that outbound investment is the inevitable result of Singapore's economic development. Teng (1998) an analysis of the characteristics and determinants of Singapore's OFDI plays an important role in the government's encouragement and active promotion among the many determinants. Taking Singapore as an example, Dai (2006) analyzes the impact of Singapore's OFDI on employment by means of empirical methods and demonstrates the impact of China's OFDI on domestic employment through comparative analysis. $\mathrm{Su}$ (2006) examines and compares OFDI from countries such as the Four Little Dragons of Asia and suggests that China should learn from their strengths. Chen (2007) believes that there are two aspects that have jointly contributed to the pace of Singapore's outbound investment: the single industrial structure of Singapore, and the excess capital and production capacity of local enterprises in Singapore. Guo (2012) explained Singapore's strategy of internationalizing its enterprises by implementing regionalization goals by building industrial parks. Using Temasek's investment in China as an example, $\mathrm{Hu}$ (2012) analyzed the Experience of the Singapore Government in encouraging and protecting enterprises to "go global". Zhang (2011) believes that Singapore's OFDI has also played a more obvious role in promoting technological progress in home countries. Lin (2014) studied Singapore's OFDI strategy and compared it with China to summarize the lessons Singapore can give China. Sun and Li (2020) have calculated through risk assessment that Singapore is a low investment risk country.

The above studies provide the theoretical basis for this paper, which will summarise Singapore's insights for China in terms of OFDI, based on an analysis of the current situation of Singapore's OFDI, taking into account the similarities and differences between Singapore and China in this regard.

\section{The Status Quo of Singapore's OFDI}

\subsection{The Stock and Flow of Singapore's OFDI Are on the Rise}

Singapore's total OFDI stock reached $\$ 351$ billion at the end of 2019, up nearly 2.6 times from $\$ 135$ billion in 2009 (Figure 1). Since the 21st century, the overall 


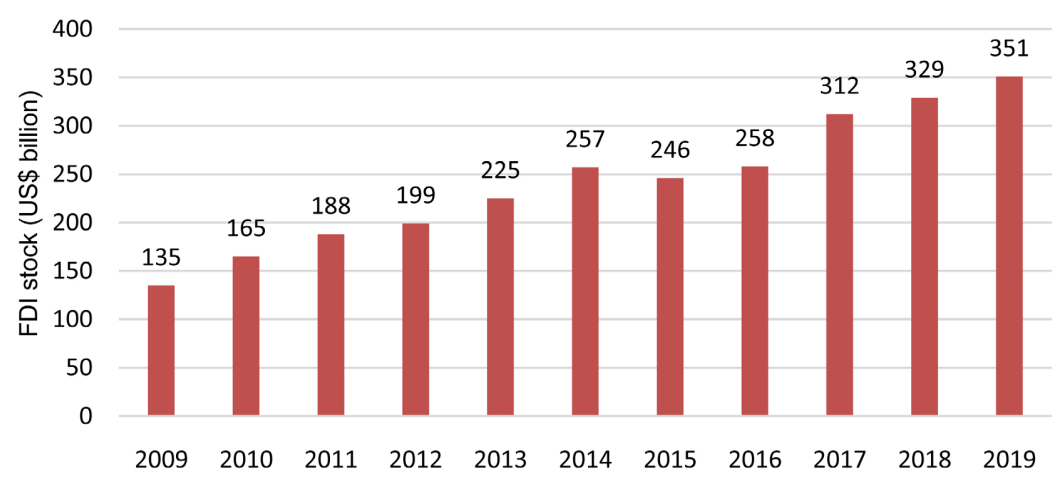

Figure 1. SINGAPORE FID stock 2009-2019 (US \$ billion, Data source: World Investment Report).

trend in Singapore's total OFDI stock is growing, with abundant domestic capital and increasing demands on foreign investment. Before the US subprime, crisis Singapore's stock of OFDI grew faster. Singapore's OFDI stock declined in 2008 as a result of the subprime crisis, but by 2009 Singapore's total OFDI stock had increased rapidly, up $18 \%$ from 2008, and had also maintained double-digit growth rates in 2010, declining from 2011 to 2015, but overall trending was still growing.

FDI traffic in Singapore is on the rise but will decline in 2020 due to the new crown outbreak. FDI inflows in Singapore fell 21\% to $\$ 91$ billion (Figure 2). Even so, Singapore remains the largest recipient and source of investment in the region. FDI declined in the top three receiving sectors (finance, wholesale and retail trade, and manufacturing), with manufacturing investment falling the most, by more than $80 \%$.

\subsection{Singapore's OFDI Sector Is Mainly Located in the Service Sector}

In Singapore's OFDI industry, the financial and insurance industry continues to be the leading sector of SINGAPORE's OFDI. In 2019, Singapore's total financial and insurance investment amounted to US $\$ 455.38$ billion, accounting for $48.7 \%$ of total OFDI. Singapore's other two key OFDI sectors are manufacturing and real estate, with manufacturing outbound investment of US $\$ 182.34$ billion in 2019 , accounting for $19.5 \%$ of total OFDI, and real estate investment of US $\$ 69.25$ billion, accounting for $7.4 \%$ of total OFDI. The analysis shows that the service sector is the focus of Singapore's OFDI, accounting for $72 \%$ of Singapore's total OFDI, while manufacturing and construction account for only $21 \%$ of TOTAL OFDI (Table 1).

\subsection{Singapore's OFDI Region Is Mainly in Asia}

Singapore has a wide range of outbound investments but absorbs more overseas investment in China, Europe, ASEAN and Central and South America.

Singapore's share of total OFDI in the Asian region fell from 57\% in 2012 to 54\% in 2019, while its share of investment in South America, Central America 


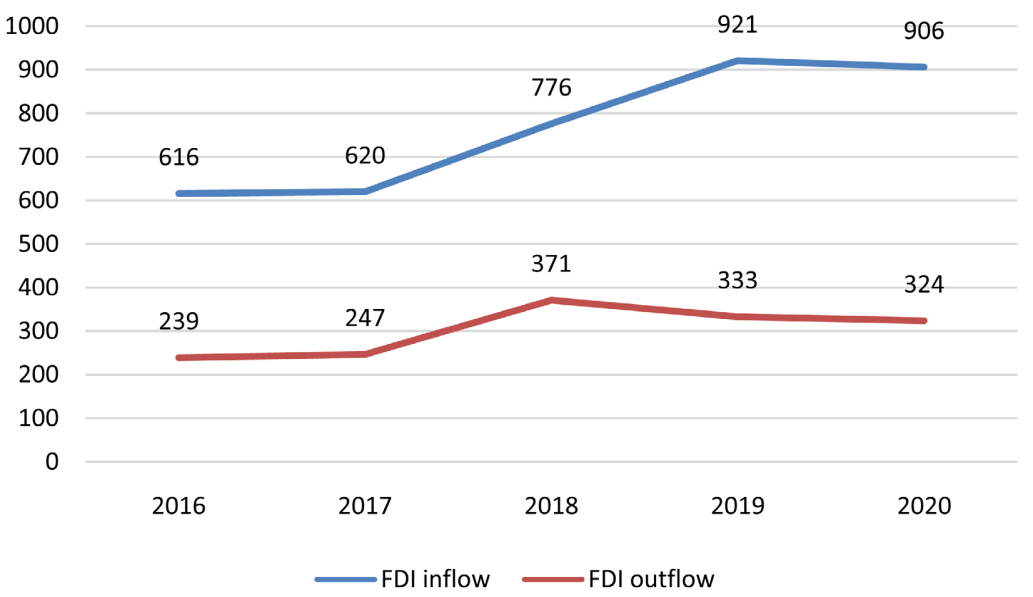

Figure 2. Inflows and outflows of Singapore's OFDI 2016-2020 (US \$ billion, Data source: World Investment Report).

Table 1. OFDI by various sectors in Singapore 2015-2019 (US \$100 million).

\begin{tabular}{cccccc}
\hline industry & 2015 & 2016 & 2017 & 2018 & 2019 \\
\hline Financial and insurance industry & 3562.4 & 3902.3 & 4122.5 & 4046.9 & 4553.8 \\
Manufacturing & 1373.1 & 1578.4 & 1744.4 & 1743.4 & 1823.4 \\
Real estate & 563.3 & 664.9 & 686.6 & 687.3 & 692.5 \\
Wholesale and retail trade & 612.5 & 706.2 & 748.7 & 722.4 & 751.5 \\
Information and & 312.5 & 385.9 & 380.4 & 390.9 & 404.4 \\
$\begin{array}{c}\text { communications industry } \\
\text { Transportation and }\end{array}$ & 204.6 & 188.1 & 161.8 & 178.8 & 183.6 \\
warehousing industry & & & & & \\
Professional and technical services & 217.1 & 247.2 & 238.5 & 252.9 & 253.6 \\
Hotel and catering industry & 43.8 & 47.4 & 49.5 & 53.2 & 50.8 \\
Construction & 18.9 & 22.1 & 24.9 & 22.8 & 23.6 \\
Else & 355 & 654.4 & 683.9 & 558.8 & 609.8 \\
Total & 7263.4 & 8397.4 & 8841.6 & 8657.9 & 9347.8 \\
\hline
\end{tabular}

Data source: Department of statistics of Singapore, Singapore's investment abroad, 2019.

and the Caribbean did not increase or decrease significantly. Singapore's TOTAL OFDI stock in Asia will reach US $\$ 501.3$ billion by 2019 (Figure 3), with US \$128.4 billion invested in South America, Central America and the Caribbean, about a quarter of its investment stock in Asia. Singapore's share of OFDI to developed countries in Europe and the United States remains roughly at a moderate level.

China overtook Malaysia in 1998 as the biggest inflow of Investment from Singapore. Singapore's top investor in Asia and the world remains China in 2019 , with an OFDI stock of $\$ 147$ billion (Table 2). Singapore's OFDI to China remained stable compared to 2018, with investment in mainly manufacturing and real estate. 


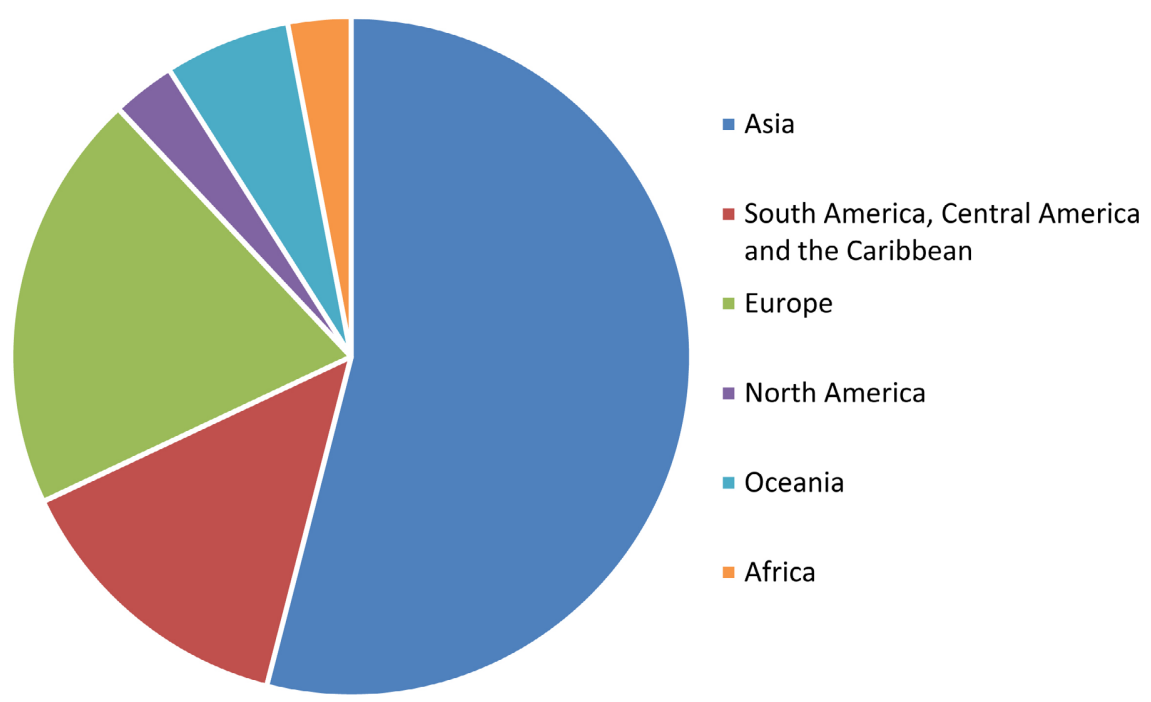

Figure 3. Regional distribution of OFDI in Singapore in 2019.

Table 2. Changes in Singapore's OFDI stock in major Asian investors 2018-2019 (US \$ billion).

\begin{tabular}{ccc}
\hline & 2018 & 2019 \\
\hline Asia & 4773 & 5013 \\
China & 1405 & 1470 \\
Hong Kong & 572 & 576 \\
Malaysia & 487 & 542 \\
Indonesia & 664 & 652 \\
Thailand & 259 & 311 \\
\hline
\end{tabular}

Data source: Department of statistics of Singapore, Singapore's Investment Abroad, 2019.

Of concern is Singapore's stock of OFDI in neighboring Malaysia, which is down 10 percent year-on-year compared to 2018, mainly in the financial and insurance industries and manufacturing sectors. In the investment industry, there has been no significant change in the total investment stock of Hong Kong, China, which mainly invests in the financial and insurance industries, accounting for about $70 \%$ of the total investment.

\section{The Problems Facing Singapore's OFDI}

Singapore actively implements the OFDI strategy, and at the same time faces many problems and hidden dangers, through the analysis of the status quo and main practices of Singapore's OFDI, we can see that Singapore in the implementation of the OFDI strategy, the main problems facing Singapore are the following three aspects.

\subsection{Vulnerable to Changes in the External Environment}

Because of Singapore's high degree of external dependence, it is vulnerable to changes in the economic situation at home and abroad and has a deep impact. 
Singapore's outbound investment flows fell sharply in 1998, 2002, 2003 and 2020, while the major domestic and foreign events corresponding to those years were the Asian financial crisis of 1997, the global economic downturn in 2001, the SARS crisis in 2003, the US subprime crisis in 2008 and the covid-19 outbreak in 2019. The covid-19 outbreak had a huge impact on the global economy, with China already known as Singapore's top destination for OFDI for a decade, and the outbreak and prevention and control measures have created serious obstacles to financial flows, resulting in a $37 \%$ drop in foreign investment in Singapore in 2020 compared to 2019. The main causes of these phenomena are the fragility of Singapore's own economy, which has been highly export-oriented since independence and is heavily dependent on foreign markets. A little volatility in the foreign market economy can threaten Singapore's domestic market and thus affect Singapore's OFDI.

\subsection{Lack of Understanding of the Countries in Which They Invest}

When an enterprise invests abroad, cultural differences can lead to cultural conflicts, which increase transaction costs and reduce investment efficiency. Suzhou Industrial Park is an important cooperation project between China and New Zealand. However, the initial investment income of the park was far less than expected. Mainly because China and Singapore in the economic development, have different management concepts, the differences in the concept of the two sides and Singapore's lack of understanding of China's local business environment, resulting in some business cooperation projects results are not satisfactory.

\subsection{Vulnerable to the Influence of the Population of the Country in Which the Investment Is Made}

Singapore's investment in the host country often provokes local patriotic people to block, when large multinational companies to the investment country's enterprises to buy, mergers and acquisitions, may receive the local patriotic people of the enterprise obstruction, such as Singapore Temasek Holdings in the investment in Merrill Lynch, in the subprime crisis into the global investment sector, Temasek still choose radical investment methods, Merrill Lynch is also deep in the subprime crisis, Temasek has also taken nearly $219.7 \mathrm{~m}$ shares of Merrill Lynch amid boos and abuse at home.

\section{Singapore's OFDI Proposal}

In response to the above major problems encountered in the process of OFDI, the Singapore Government has taken corresponding measures, the main countermeasures are.

\subsection{Take Action Based on Different Events}

The reasons and impact of different events on Singapore's outbound investment are different, so the Singapore Government usually takes different measures to 
respond to them. In the wake of the 1997 Asian financial crisis, Singapore was forced to adopt a tightening economic policy to stabilize the country's macroeconomic situation. But since 1998, the Singapore government has changed course, implementing expansionary fiscal and monetary policies, implementing recession-mitigation programs, increasing domestic investment and accelerating outbound investment, led by state-owned coalitions, to emerge from a severe recession. In the context of the global economic downturn in 2001 and the SARS crisis of 2003, Singapore has taken a number of measures to restructure its economy, restructure its industrial structure, strengthen export competitiveness, expand Singapore's economic hinterland, gradually increase regional and global capabilities, and develop and commercialize knowledge capital. In general, it is mainly through economic growth to expand the strength of their own outbound investment. After the US subprime crisis, Singapore began to shift its outbound investments to regions and industries, increasing investment in Asia and investments outside the financial and insurance sectors, a diversified portfolio that helped Singapore's outbound investment growth.

\subsection{Fully Understand the Environment and Policies of the Investing Countries}

After many international economic shocks, When Singapore cooperated with the host country to establish an industrial park, it was no longer limited to the form of an industrial park dominated by manufacturing, but focused on combining the actual situation of local economic development and selecting suitable new park models such as eco-city, food area, science and technology park and so on. Prior to the investment, the host country's cultural background, business system and management concepts for in-depth analysis, in addition to the national level, but also with the host country's local government, that is, the local level to invest in the construction of industrial parks, in cooperation with the host country's business management concept for effective integration, rather than completely copy the domestic park model, the domestic park in line with the characteristics of the host country to introduce some of the management experience to take advantage of.

\subsection{Encourage Small and Es to "Go Out"}

The Singapore government called on the vast number of small and mediumsized enterprises in China to actively "go out" and provide them with a large amount of information, capital, technology and personnel support for SMEs to better provide a full range of services for FOREIGN direct investment. If small and medium-sized enterprises need to consult with specialized agencies in foreign markets, the government helps to pay $50 \%$ of the consulting fees, EDB staff often and the heads of small and medium-sized enterprises to study the market, looking for partners, for the need to go abroad to understand the market, the Singapore Government to reimburse round-trip air tickets, but also provide sub- 
sidies for venue rent.

\section{The Enlightenment of Singapore's ODFI to China}

Singapore's experience in actively using outward investment to develop its own economy has been successful in the light of its own realities, and although Singapore and China have different development models and specific circumstances, many of Singapore's practices and ideas in OFDI, as well as the use of foreign investment, still have something to learn from and learn from China.

\subsection{Take Advantage of Location Advantages and Give Full Play to Your Own Advantages}

Singapore is strategically located in the Pacific and Indian Oceans. Singapore's independence, lack of funds, but Singapore combined with its own advantages, transportation, communications and other infrastructure in the main position, and constantly expand the maritime, aviation, shipbuilding and supporting warehousing, transportation and other services, the location advantage into an economic advantage, thereby attracting investment from all over the world. It can be seen that location advantage plays an important role in Singapore's outbound investment.

And China's vast territory, many neighboring countries, China should take advantage of this advantage, after economic analysis of these countries, the use of location advantages to investing. At present, more than $60 \%$ of China's enterprises' OFDI is concentrated in Hong Kong, and the development of ASEAN countries with great potential for development is not enough. ASEAN is rich in natural resources and is similar in cultural customs to China, while the imbalance in the development of countries in the region leads to low factor costs in some countries, while some countries have better service industry development, which is conducive to China's targeted direct investment. The China-ASEAN Free Trade Area provides many convenient and development opportunities for trade and investment between China and ASEAN.

\subsection{Strengthen the Analysis of Domestic and Foreign Investment Situation, Avoid Risks}

Singapore's highly export-oriented economy has led to its external bad situation, investment host country's influence, and the enterprise itself when investing abroad, it is vulnerable to the impact of the outside economy, large to the global economic situation, the global financial crisis, small to the host country political instability, public obstruction. Therefore, for Singapore and China, an understanding of the domestic and foreign economy and investment situation is essential. The first thing to understand is the relevant laws and regulations of the host country, pay attention to the local political situation is suitable for investment, at the same time to the country's economic situation and the global economic situation to carry out a serious analysis, cannot blindly invest. In addition, we must be prepared to avoid risk avoidance, to avoid total military cover-up. 


\subsection{Improve the Level and Quality of Foreign Capital Utilization and Improve Competitiveness}

Singapore has been adjusting its industrial structure in time for higher economic growth rates, and since 2000 it has increased its investment in knowledge-intensive industries and added some high-tech, high-value-added industries. To the world as a market, give full play to their own advantages, in order to continuously obtain the world's advanced areas of investment.

For our country, while expanding the scale of investment, we should improve the level and quality of foreign investment and foreign investment, focus on advanced technology, professional personnel, combined with industrial restructuring, improve industrial competitiveness.

\section{Concluding Remark}

Singapore has made great efforts to develop its economy in recent years, with great achievements in OFDI and tremendous growth in stock and flow. Singapore plays its part in foreign investment, taking advantage of its location to attract investment from all over the world. The Singapore Government has taken a series of measures to encourage SMEs to "go global" and to create opportunities for SMEs.

China's similarities with Singapore in OFDI suggest that we can also draw some inspiration from Singapore's approach: first, to take advantage of its location; These revelations can help China to better develop OFDI.

\section{Conflicts of Interest}

The authors declare no conflicts of interest regarding the publication of this paper.

\section{References}

Chen, M. (2007, July 17). Singapore's Overseas Investment Is a Big Hit. International Business Journal, No. 6, 33-34.

Dai, X. (2006). Empirical Analysis of the Impact of OFDI on Domestic EmploymentTaking Singapore as an Example. World Economy Studies, No. 4, 70-76.

Guo, J. (2012). Singapore's Export-Oriented Economic Development since Independence: Perspectives on Globalization and Regionalization. Yunnan University.

Hao, H. (1997). Attracting Foreign Investment and Foreign Investment: The Wings of Singapore's Economic Development. Journal of International Economic Cooperation, No. 7, 41-43.

Hu, W. (2012). Singapore Government Encourages and Protects Enterprises' Experience of "Going Out" and Its Enlightenment to China-Taking Temasek's Investment in China as an Example. Southeast Asian Studies, No. 4, 67-74.

Lin, Y. (2014). Singapore's Foreign Direct Investment Strategy Research. Yunnan University of Finance and Economics.

Su, L. (2006). OFDI: Theory, Practiceand China's Strategic Choices (pp. 120-136). Xiamen University. 
Sun, J., \& Li, L. (2020). Investment Risk Assessment for Countries along the Belt and Road Initiative-Taking Singapore and Six Other Countries as Examples. Modern Marketing (Information Version), No. 1, 12-14.

Teng, J. (1998). Singapore's OFDI and Its Determinants. Foreign Economies and Management, 37, 44-45.

Zhang, H. (2011). Study on the Economic Effects of OFDI on Home Countries in Emerging Economies in East Asia. Liaoning University. 